\title{
Regional identities of Czech historical lands
}

\author{
Antonín VAISHAR and JANA ZAPLETALOVÁ ${ }^{1}$
}

\begin{abstract}
Bohemia and Moravia are historical lands, which constitute Czechia (together with a small part of Silesia) since the $10^{\text {th }}$ century. Two entirely different settlement systems can be identified in Czechia: the centralistic Bohemian settlement system surrounded by a ring of mountains, and the transitional and polycentric Moravian settlement system. The two lands were physically divided by a border forest. Although they have belonged always to the same state, their autonomy was relatively high until the formation of the Czechoslovak Republic in 1918. In 1948, a new administrative division was introduced, which did not respect the border between the two lands. Bohemia and Moravia kept their importance as different cultural units only. The main research question addressed in this paper is how the Bohemian and Moravian identities are perceived by the people today and whether it makes any sense to consider the historical lands seriously when rethinking the idea of the Europe of regions.
\end{abstract}

Keywords: regional identity, administrative division, historical lands, Bohemia, Moravia, Czech Republic

\section{Introduction}

The idea of nation-state was introduced as a result of the Treaty of Westphalia (1648). Its purpose was to change the old dynastic system into a new territorial one. Nationalism, developing in the subsequent two centuries, became the main ideology all over Europe. Many times, the idea was abused for provoking wars and conflicts. In (western) Europe, the conflicts among nation-states were overcome by creating the European Union, which governed relations between two traditional enemies: Germany and France among other things. Recently, the power has shifted from the level of nation-states to multinational corporations and banks. In 2010, Herman van Rompuy, president of the European Council, declared that the idea of nation-states is over. European integration is the most important challenge in this process.

The problem of nation-states in Europe consists of - among other things - the fact that the Union is formed by countries of very different size. Small countries fear that the decision making power is dominated by the large ones. Conversely, big countries fear high participation of small countries in the decision-making process, although they provide the majority of resources for EU level programmes. The solution could be a unified Europe divided into historically grounded regions, which can be more comparable in size. Applegate, C. (1999) writes: Europe has always been and remains very much a continent of regional identities.

Keating, M. (1998) explains that regions are no longer confined with the borders of their nation-states but have become actors in European and international politics, and they find themselves increasingly in competition with each other. In this way regional identity has been increasingly identified in the EU's cohesion policy as an important element for regional development (PAASI, A. 2009).

Of course, regional identity is subject to a long term development process. Nationstates are deeply ingrained in people's minds. Nationalism is also a tempting card in the hands of populist politicians. The first

\footnotetext{
${ }^{1}$ Institute of Geonics, Czech Academy of Sciences, Department of Environmental Geography, Drobného 28, 60200 Brno, Czech Republic. E-mails: vaishar@geonika.cz, zapletalova@geonika.cz
} 
attempts to give some political power to the European regions can be traced back to the Maastricht Treaty in 1993 and the establishment of the Council of Regions one year later. PAinter, J. (2002) pointed out that the idea is more top-down than bottom-up and, thus, it is a question whether it will resonate in the regions themselves. PAAsI, A. (2001) expressed the idea that European regions are the results of regionalization processes more than historical and cultural products. Thus, the question arises whether regions, which are mostly embedded in the history, are perceived as relevant entities by their inhabitants.

Czechia consists of two historical lands: Bohemia and Moravia. In the course of history, small and discontinuous parts of Silesia were connected with the territory of the state. Since the administrative autonomy of the historical lands was gradually degrading, they have not created any administrative unit neither their borders have been kept within the borders of lower level units (regions, districts, communes).

On the other hand, it seems that cultural characteristics and differences have survived. The question is whether the borders between these historical lands are kept in the mind of people and whether this historical memory can be used to create regional and local identities and, thus, enhance regional development and cohesion in general.

\section{The identity of European regions}

Regional identity relates to the concept of us - and the others (see e.g. Neumann, I.B. 1999). According to PAAsI, A. (1986), regional identity could be divided into two parts: subjective (images of the region held by its inhabitants and those living outside of the region) and objective (based on physical or economic indicators). According to SEDLACEK, S. et al. (2009), regional identity relates to regional consciousness and regional solidarity: Regional solidarity is an aspect functioning as a landmark of a particular region, which implies a specific relationship with the region. Inhabit- ants are proud to be part of the region and have a strong territorial connection. In addition, the authors' idea on regional solidarity likely acting as a factor of regional identity is also relevant for our case study.

The concept of identity has been used since the 1980s - regional identity being a special manifestation thereof (PAAsI, A. 2003). The author defines regional identity as a relationship between a group of people and the bounding region. Regional identity is understood as an abstraction that can be used to analyse links between social actors and the process of institutionalisation (PAAsI, A. 2002). According to Chromý, P. and JANŮ, H. (2003) a particular territory with the specific social, economic or developmental conditions (specific historical development) serve as a base for forming the territorial/regional identity. Such regions are neither economic nor administrative constructs but rather realistic territorial units embedded in the mental memory of people. As Odehnal, J. and ŠErÝ, M. (2012) note, regional identity is closely related to regional borders. These boundaries play an important role in shaping the regional identity because they help to define the region, thus helping people to perceive "their" region. ToušEK, V. et al. (1991) dealt with the problem of boundaries between the Czech historical lands just after the political change.

The problem of borders and borderlands is relatively frequent in the contemporary European geography. The research is focused mostly on the consequences of the elimination of borders within the framework of European integration and later within the Schengen zone. In the mainstream literature the emphasis often lie on the changes from physical barriers to a psychological or mental one (e.g. Newman, D. 2006 and many others). As Lundén, T. and Zalamans, D. (2001) pointed out there has been a geographical refocusing of the border away from the level of the State down to internal regions, municipalities and neighbourhoods.

Which territorial units come into account to understand Europe as a unity of regions? Such units should be large enough to have 
related economic and political powers, they should be more or less comparable in size and should have some historically rooted identity. Such historical regions exist in all larger (West) European countries (Länder in Germany, Provinces historiques in France, Comuninades autónomas in Spain, Regioni in Italy, Regions in England, etc.). The boundaries of some of them are clear and unchanged during centuries; in other cases, their size was slightly changed in the past. Nevertheless, also in the western part of Europe, problems of regional identity occur as e.g. FICHTNER, U. (2006) shows on the example of the Southern Upper Rhine Valley.

The situation in Central and Eastern Europe is more complicated. Boundaries of individual states often changed in the history; historical lands were often divided by different countries. The second problem is connected with the fact that many countries in this part of Europe have gained (or regained) political independence only a short time ago. These countries are much more anchored in the perception of nation-states. Nevertheless, also in these countries, historical regions do exist and could be identified.

After the fall of communism, many questions, which were tabooed in the past, were put forward including the problem of ethnicity. In the 1991 Czech population census, respondents were offered to declare the Moravian or Silesian nationality. About 1.4 million inhabitants of the Czech Republic identified themselves as Moravian or Silesian nationality, which was not allowed before. They expressed their awareness of belonging to the historical provinces of Moravia and Silesia and, thus, belonging to the Czech nation. Thus, a new social division has developed in the ethnically nearly homogeneous environment of the Czech Republic, which constitutes a potential threat for the further splitting of the State (DANĚK, P. 1993). It is probably the most important reason why politicians refuse a return to the original division of the country based on the historical lands.

ŠERÝ, M. and ŠIMÁČEK, P. (2012) analysed the boundaries of regional identity on the example of the Moravian-Silesian divide in the
Jeseník district based on the concept of mental maps. They stated that regional identity is relatively weak. However, it is necessary to note that the original population of the Jeseník area was almost completely replaced after World War II; therefore, its regional identity became weakened in general. On the other hand, it is also important to emphasise that the land's identity is only a part of the regional identity.

In the 1991 population census, it was possible to declare the Moravian and Silesian ethnic background besides the Czech nationality. At that time, about 1.3 million inhabitants declared the Moravian nationality (13\% of the population). It was partly connected with the efforts of some Moravian microregions to be connected with Moravian districts or regions and with the political ambitions of some Moravian politicians. In the 2001 census, only 400,000 people declared the Moravian ethnicity (3.7\% of the population). The issue of some administrative changes was not on the agenda at that time. In the 2011 census, answers to questions about ethnicity and religiosity were voluntary. As a consequence, about a quarter of the respondents did not replay to that question. Yet, the number of "Moravians" (in the English, and namely in the US literature, the term Moravian is connected more with the affiliation to the Moravian Church which originated from the Unitas Fratrum Church) increased to 522,000 (5.0\%). The main research question addressed in this paper is how the Bohemian and Moravian identities are perceived by the people and whether it makes any sense to consider the historical lands seriously when rethinking the idea of the Europe of regions.

\section{Bohemian-Moravian relations, differences and perceptions}

Bohemia and Moravia are historical lands, which constitute Czechia since the $10^{\text {th }}$ century. The two lands used to be physically divided by a border forest. On the one hand, 
since the eclipse of the Great Moravia Empire Moravia has always been peripheral in relation to Bohemia (due to multiple reasons and conditioned by supranational culture represented by the Catholic Church). Nevertheless, the subordination of Moravia has never been absolute (ŠEDO, J. 2002). On the other hand, Moravia has always been an important hinterland for Bohemia and its peripherality provided a good basis to keep some traditional culture.

In spite of having always been parts of the same state, the two lands had relatively great autonomy until the formation of the Czechoslovak Republic in 1918. In the period between 1918 and 1938, Bohemia and Moravia (later Moravia-Silesia) were two of the four main administrative units of the state, Slovakia and Carpathian Ruthenia being the other ones (Figure 1). Only in 1948, a new administrative division was introduced, which did not respect the border between the two lands. Bohemia and Moravia always kept their importance as different cultural units whereas the role of Silesia became less clear. The historical lands of Bohemia and Moravia are two regions whose existence the Czechs recognise without a question, while Silesia is in a weaker position and gains only two-thirds of the recognition of the other two historical lands (SIwEK, T. and Bogdoví, K. 2007).
After 1989, some political parties and movements focusing on the Moravian issue arose. The Movement for Self-Governing Democracy - Association for Moravia and Silesia was the most successful among them. Moravian ethno-regional parties mostly supported the idea of the European integration and the Europe of Regions - often in contrast with some leading nationwide parties like the Civic Democratic Party (MAREš, M. 2002). The country was newly divided into 12 administrative regions, which did not respect the historical borders and did retain any historical identity (Figure 2).

The issue of Moravian autonomy was gradually replaced by other questions. In general the low level of political interest of people (expressed by extremely low participation of people in elections; e.g. in 2014 in the last elections to the European Parliament the turnout rate was only $18.2 \%$ ) and re-orientation towards consumption could be the main reasons. A certain resignation to regional issues in relation to social problems (economic crisis, unemployment, low incomes, and poverty) could also be mentioned.

Are there some measurable cultural or social indicators of differences between the two lands? Investigating the social capital in Czechia, Pileček, J. and JANČÁK, V. (2010) talk about the polarisation between Bohemia and

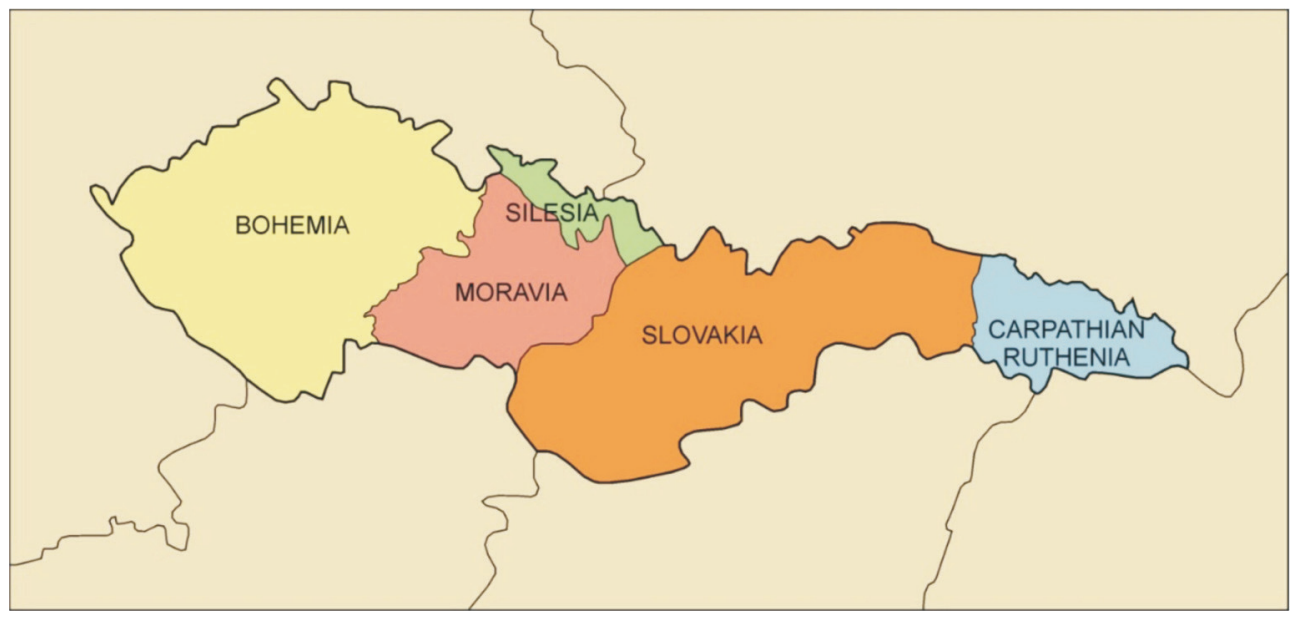

Fig. 1. Lands of the First Czechoslovak Republic, 1918-1938. (Drawn by J. Poкorná.) 


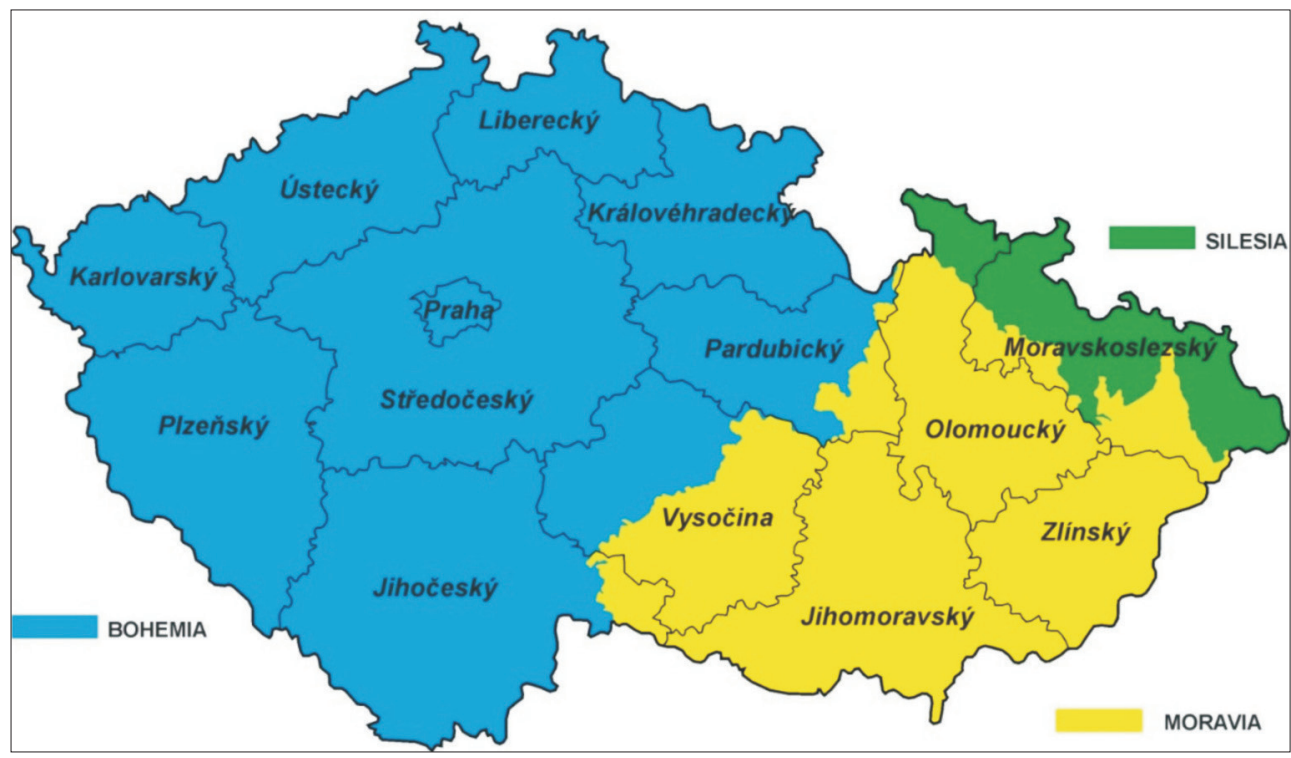

Fig. 2. A comparison of historical lands and the present administrative division of the Czech Republic. (Drawn by J. Pokorná.)

Moravia (at a district level) - highlighting the difficulties of measuring. The cultural identity of Moravians is often reflected in the establishment of clubs focusing on the promotion of Moravia as a historical territory with the effort to keep or renew Moravian identity. There are 12 such clubs registered by the Ministry of Interior.

If Moravia is a periphery of the Czech state, is the Czech part of Silesia a periphery of the periphery? SiwEK, T. (2006) answers the question positively reasoning with the remote geographical position, major economic problems (transition from heavy industry) and the mental distance of people. In our opinion, he does not take into account enough the fact that Silesia is more urban than Moravia which could also play a role in the conditions of peripherality.

From an urban geographical point of view, two different settlement systems can be identified in Czechia: the centralistic Bohemian system surrounded by a ring of mountains and the transitional and polycentric Moravian urban system. The dominant position of Prague, its economic power, and the low competitiveness of Moravian centres is probably the main reason for Moravian backwardness. Moravia (being more rural) was more able to keep some ethnographical traditions. It is divided among several ethnographical regions whereas Bohemia is ethnographically more or less homogeneous an exception is being Chodsko in the Domažlice district (see SiwEK, T. 2012).

Differences are also emphasised in the presentations of individual regions in the media - which has to do with the image of individual regions. SUCHÁčEK, J. et al. (2013) show that Moravian (NUTS 3) regions are much less presented in national TV (in relation to their population numbers) than the Bohemian ones (Figure 3).

Nevertheless, it cannot be said that the main reason is a discrimination of Moravian regions. Individual regions are usually presented as regions - not as parts of Bohemia, Moravia or Silesia. The frequency of the contributions depends on cultural and economic activities as well as on the social conditions of individual regions. In this respect Prague the capital city plays the most outstanding role. 


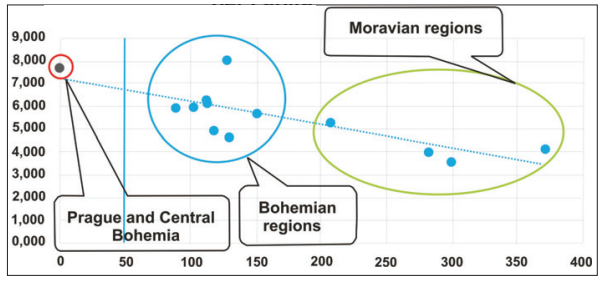

Fig. 3. Linear regression model expressing relations among distances, populations and the number of contributions per capita for all NUTS 3 regions (Prague and Central Bohemia united). $y=-0.0102 x+7.21$; $R^{2}=0.6033$. Source: SUCHÁČEK, J. et al. 2013.

The issue of historical lands is probably perceived differently from the Bohemian and Moravian side (similarly as the perception of Czechoslovakia from the Czech and the Slovak side). On the one hand, for Bohemians (who feel themselves as the leading power in the country) the problem does not exist and if so, it is perceived as a decentralising separatist tendency. On the other hand, in Moravia, the issue is understood in different ways, sometimes as an ethnic problem, another time as a regional problem or cultural difference. Moreover, Moravia (unlike Bohemia) features greater ethnic diversity.

Cнromý, P. et al. (2004) tried to investigate regional identity in Czechia. They concluded that a visible dichotomy exists between the "traditional" Moravia and the "modern, quickly changing" Bohemia. They came to the conclusion that traditional historical regions persist long in the mind of people. However, it does not seem that the same would apply for the borderline itself (depending on the situation of individual sections of the border). To put it short, the centres of historical regions are clear, while the borderline is fuzzy. In reality, the borderline is often equated with administrative boundaries.

\section{Mental manifestation of borders between the Czech historical lands}

The border between Bohemia and Moravia has partly natural character. It more or less respects the limits between the Labe (Elbe)
River and Danube River basins. Originally, it was covered by a border forests. The borderland between Bohemia and Moravia belongs to the Czech inner periphery. According to Musil, J. and MüLleR, J. (2008) inner peripheries can be generally defined as territories that are not economically expanding, are losing population, are demographically ageing, have lower socio-economic status, have worse technical and social infrastructure compared to that in other parts of the country, are less accessible, have older housing stock, and are experiencing specific exclusion-related social problems.

It is more or less true for the majority of border sections between Bohemia and Moravia and for the western part of the Moravian-Silesian borderland. The situation is supported by the fact that the borderline leads through the highland terrain far from the regional centres. The weakest regional centre of Jihlava (Vysočina - Highland Region) is the only exception, being situated just on the borderline. The eastern part of the Moravian-Silesian borderland has different conditions. It is situated in a relatively urbanised area not far from the Ostrava Basin - the third largest regional centre in Czechia.

In our research ethnicity declarations of local residents in 199 communes in the Bohemian-Moravian borderland were analysed (103 in the historical Bohemia, 96 in Moravia). Problem arose from the fact that the Czech language has the same word "česky" for both meanings - Czech and Bohemian. Thus, it is not clear whether respondents declared themselves Czechs in terms of nationality, or Bohemians or Moravian in terms of ethnicity in the population censuses of 1991 and 2011 as shown in Table 1 (share of the two ethnicities decreased because ca. $25 \%$ of inhabitants did not declare any ethnicity in 2011).

It is clear that the mixing of terms of the Czech/Bohemian nationality and ethnicity does not allow operating with the shares of individual ethnicities. However, it is more or less clear that although the ratio of Moravian ethnicity is higher on the Moravian side of the border, its share has decreased during the last two decades. 
Table 2 shows the situation in detail in selected communes just on the border. All the communes are originally Moravian towns located outside of typical Moravian administrative regions or just on the borderline. Only one of them (Jevíčko) shows a clear tendency to be affiliated with Moravia.

It can be concluded that not only the share of Moravians decreased by 2011 in comparison with 1991 (see Table 3), but the attention paid to the issue of ethnicity has also become much less in the Bohemian-Moravian borderland. Nevertheless, since the Czech population and the Czech language do not differ between nationality and ethnicity, it is difficult to formulate robust conclusions concerning regional identity.

Regarding the fact that the administrative structure of Czechia does not respect the traditional border between historical lands, the question concerning the affiliation of 51 selected towns to Bohemia or Moravia was put forward (of them, 3 towns are situated just on the borderline - partly in Bohemia, partly in Moravia) and a survey using the method of random sampling among respondents between 20 and 80 years old with secondary or tertiary education was conducted. We thought that these people could have some geographical and historical knowledge including the Bohemian-Moravian relations. We received altogether 49 responses where only a small part of the answers was correct. Mistakes were made partly in cases where historical Moravian towns are situated in regions falling more to Bohemia. In addition, geographical knowledge was poor because the knowledge of people depends very much on the size of the individual towns and distance from respondents' home.

As a next step, members of the Voluntary Associations of Communes were checked. Under Czech conditions, small (200-500 inhabitants) and very small (under 200 inhabitants) municipalities participate in such associations very frequently, especially in the peripheral areas, including the Bohemian-Moravian frontier zone. The question was whether the associations created within this process respect administrative or historical borders. Altogether

Table 1. Ratio of people declaring Bohemian and Moravian ethnicities on the Bohemian-Moravian borderland in the 1991 and 2011 censuses

\begin{tabular}{l|c|c|r|r|r}
\hline \multirow{2}{*}{ Communes } & \multirow{2}{*}{$\begin{array}{c}\text { Total population, } \\
\text { person }\end{array}$} & \multicolumn{2}{c|}{ Bohemian } & \multicolumn{2}{c}{ Moravian } \\
\cline { 3 - 6 } & \multicolumn{7}{c}{ person } & $\%$ & person & $\%$ \\
\hline Bohemian & 74,491 & 70,670 & 94.9 & 2,563 & 3.4 \\
Moravian & 154,410 & 132,885 & 86.1 & 14,837 & 11.8 \\
\hline \multicolumn{7}{|c}{2011} \\
\hline Bohemian & 77,247 & 53,348 & 69.1 & 644 & 0.8 \\
Moravian & 148,737 & 98,905 & 66.5 & 9,360 & 5.0 \\
\hline
\end{tabular}

Source: The Czech Statistical Office, Prague.

Table 2. Ratio of people declaring Bohemian and Moravian ethnicities in some Moravian towns in the 1991 census

\begin{tabular}{l|c|c|r|r|r}
\hline \multirow{2}{*}{ Town } & Total population, & \multicolumn{2}{c|}{ Bohemian } & \multicolumn{2}{c}{ Moravian } \\
\cline { 3 - 6 } & person & person & $\%$ & person & $\%$ \\
\hline Dačice & 7,970 & 6,363 & 79.8 & 1,502 & 18.8 \\
Slavonice & 2,543 & 2,328 & 89.0 & 213 & 8.1 \\
Jihlava & 50,439 & 48,007 & 91.9 & 2,423 & 4.4 \\
Svitavy & 16,860 & 15,752 & 90.3 & 1,107 & 6.3 \\
Jevíčko & 2,615 & 1,490 & 55.4 & 1,123 & 41.8 \\
Moravská Třebová & 11,700 & 8,912 & 73.8 & 2,756 & 23.1 \\
Žd'ár nad Sázavou & 25,198 & 20,439 & 79.8 & 4,755 & 18.6 \\
\hline
\end{tabular}

Source: The Czech Statistical Office, Prague. 
Table 3. Ratio of people declaring Bohemian and Moravian ethnicities in some Moravian towns in the 2011 census

\begin{tabular}{l|c|c|c|r|r}
\hline \multirow{2}{*}{ Town } & Total population, & \multicolumn{2}{c|}{ Bohemian } & \multicolumn{2}{c}{ Moravian } \\
\cline { 3 - 6 } & person & person & $\%$ & person & $\%$ \\
\hline Dačice & 7,492 & 5,388 & 71.9 & 153 & 2.0 \\
Slavonice & 2,455 & 1,533 & 62.4 & 25 & 1.0 \\
Jihlava & 50,075 & 35,495 & 70.9 & 737 & 1.5 \\
Svitavy & 16,670 & 11,821 & 70.9 & 404 & 2.4 \\
Jevíčko & 2,886 & 1,737 & 60.2 & 324 & 11.2 \\
Moravská Třebová & 10.543 & 6,669 & 43.3 & 941 & 8.9 \\
Žd'ár nad Sázavou & 22,328 & 15,300 & 68.5 & 1,364 & 6.1 \\
\hline
\end{tabular}

Source: The Czech Statistical Office, Prague.

27 associations were checked. In the vast majority of the cases, the associations prefer to respect district borders (although districts are only of statistical importance since 2003) also when the district border is different from the historical one. It is understandable: the collaboration across the administrative border would be probably more complicated. On the other hand, the historical borders were crossed only in five cases.

\section{Discussion: Do historical lands have some importance today?}

The European Union should be a political body (re)establishing historical borders. The process has two sides: a top-down approach is necessary in the case of public administration. Everyday practices of local people should also be taken into account. Forming voluntary associations of municipalities manifests a bottom-up approach. It is interesting that association crossing the state borders (euro-regions) developed relatively intensively whereas association crossing the regional borders are very rare. The reason lays in financial issues. Whereas euro-regions are financially supported by the EU, the chances of associations do not increase in the case of cross-regional purposes.

Due to the abandonment of the historical division of the state in 1949, changes in social and cultural values of people as well as the transformation of the educational system (i.e. less importance of regional specialties), the awareness of the historical affiliation to
Bohemia, Moravia or Silesia has gradually declined in Czechia. People do not doubt that these historical lands exist, they are able to define their core territories and they have some imaginations about differences in language or some habits, but they are not certain about their borderlines. In spite of this, some enthusiasts try to assemble boards, characterizing former borderlines in certain border sections.

We do not suppose that the Moravian or Silesian ethnicity means a creation of a special Moravian ethnicity at the expense of Czechs (or penetration of Silesians from Poland to the Czech territory). The Moravians and Silesians are no minorities in their own territory. If the declaration of Moravian or Silesian in the population census means a creation of a new ethnicity, the decrease of Moravians and Silesians between the censuses should not be so significant. We believe that such statements meant mainly the expression of regional identity and a requirement of deeper subsidiarity at the regional level in response to the centralism of Prague.

IščUK, R. (2011) maintains that Moravian identity is declining at the present time. Nevertheless, he is of the opinion that regional politics of the European Union should provide new impulses to the Moravian issue by leaving the centralizing tendencies and asking for new regional identities. He sees three possible options for the future development: (1) option of the Balkans - a change of the regional principle into the ethnic one; (2) the European option - weakening the nation-states and strengthening the regions; or (3) the homogeneous option - leaving the European ideas 
and returning to the nation-states. Together with the author, we prefer the $2^{\text {nd }}$ option.

In this connection, let us put a legitimate question: Would the restauration and preservation of the Moravian (and Bohemian, possibly Silesian) identity be really an engine for some regional development? Semian, M. and Chromý, P. (2014) mention different types of regional identity in relation to regional development:

- regional identity as a successful driver in regional development (which is realized mostly in the field of tourism development and/or as a support of collaboration among actors);

- regional identity as an unsuccessful driver in regional development (especially in cases when the identity is directed to visitors or newcomers - not to permanent residents);

- regional identity as a barrier to regional development (when the identity is directed inwards the community and does not allow a penetration of new ideas).

It follows that if the Moravian or Bohemian identity should be successful, differences must not be overemphasised. Regional identity should be the identity within the Europe of regions rather than against the Europe of regions. It has to keep particularities but must be also opened to new ideas at the same time.

With which territorial units does Czechia want to join such an idea? With the whole country? With small regions? With some statistical units (NUTS 2) without their own identity, self-government or territorial logic?

The historical lands are large enough for the competition among historical European regions; they have long historical roots, contain autonomous settlement systems. The question is whether it is not too late to return regional identity to their inhabitants.

If so, the borderlines should be defined newly. There should be only one difficult problem to solve: the NUTS 3 region of Vysočina (Highland). The region has been created in the territory of the BohemianMoravian Highland as an area unifying peripheral parts of both Bohemia and Moravia. Its centre Jihlava is the weakest centre among regional capitals (Karlovy Vary is in similar position in many sense). The city of Jihlava is not able to organise the whole territory of the region - large parts of it gravitate in reality to neighbouring Bohemian and Moravian regional centres: Brno, České Budějovice, Pardubice. However, the region connecting two peripheries is strangely not the most problematic one within Czechia. Although objective conditions are poor, probably the social capital of people living there for ages caused that present indicators rank the Highland with the prospective areas.

Jihlava is a historical royal mining town, the centre of which is situated in Moravia. However, some suburbs and a big part of its catchment area belong to Bohemia. Restoration of the historical border would interrupt relatively firm relations within the micro-region of Jihlava. But if it is the only obstacle, it should be solved: either to keep the historical border or to keep the microregion of Jihlava and affiliate it either to Bohemia or to Moravia. A similar situation (at a smaller scale) can be found for example in the micro-region of Žd'ár nad Sázavou. The solution could be similar.

The decision is a matter of political will. The return to the historical division would mean some reduction of the power of Prague as a centre for 14 small regions. However, if the European politics is directed towards the limitation of the power of nation-states and towards increasing autonomy of regions, some decisions will be necessary.

Disagreement could also come from the other side. Whereas Bohemia is a centralized, ethnically homogeneous land with the prominent centre in Prague, Moravia is different. The land consists of more ethnologically different parts like Moravian Slovakia, Wallachia, Horácko, Haná, Lachia, Moravian Silesia etc. Will the inhabitants of all these parts agree with the creation of a unified land? And which city should be the capital? Olomouc, Brno and Znojmo were the first historical competitors for this position. Later, Olomouc as a seat of the Moravian archbishop gained the role, which was lost in the $17^{\text {th }}$ century in favour of Brno. Later, with the increasing importance of heavy industry, 
Ostrava grew as a competitor of Brno. At the present time, Olomouc has fallen to the level of middle-sized city and Ostrava in the marginal position fights with structural and environmental problems. It seems that Brno with quaternary functions is a clear Moravian centre. But will other cities respect this situation? There are many unclear aspects in this regard. It does not mean, however, that it makes no sense to think about them.

Within the Austro-Hungarian Monarchy, the administrative division according to historical lands was no problem. It was probably due to the fact that the empire was a multi-national state. The First Czechoslovak Republic (1918-1938) kept the historical lands too - although it originated as a nation-state (not taking into account relations between Czechs and Slovaks and the German problem). The abolition of historical lands could be linked to the rise of the nation-state and hard centralism of the post-war Czechoslovakia. Does the European Union represent a chance for the return to the historical identity?

\section{Conclusions}

To answer the research question, we can conclude as follows: there is no doubt that the perception of historical regional identity is gradually decreasing. In contrast with some other cases like the Basque country, Catalonia, Scotland, Wallonia/Flanders etc., Moravians are interested neither in the separation from Bohemia nor in some level of political autonomy. The differences are understood rather as cultural modifications in terms of dialects, customs, folk culture etc. Efforts were directed rather to the unification of historical lands - similarly as e.g. in Brittany. We can also conclude that the Bohemian/Moravian issue is not a problem of nationality.

However, awareness about Moravia among people exists and it does not seem to be weakening. Its centre of gravity moves from the ethnic and regional concept to the cultural one - similarly like earlier in the case of ethnographic groups, e.g. Moravian
Slovaks, Wallachians etc. It is typical for the regionalisation of such groups that the core of their territory is generally known but the borders are fuzzy. It follows that when regional identity is not reflected in the administrative division of the country, it loses the strict delimitation by borders in the geographical sense, although the awareness of identity sustains or even increases.

Utilisation of historical lands for European regionalisation is another issue. There are clear evidences that subnational or regional scales have become much more important as a locus for social and political life over the last 30-40 years (JefFerY, C. 2014). Nevertheless, it is hardly possible without a corresponding regional government. Czechia is one of the few countries, which is actually not divided into historical regions with long-term identities. Administrative regions, the delimitation of which changes every 20 years are not able to play such a role.

If we think about the Europe of Regions, historical lands seem to be optimum regions concerning their size, historical development and cultural features. Further research should be focused on the Bohemian/Moravian issue as a problem of regional division based on historical roots - rather than as a problem of Moravian nationality.

Acknowledgement: The work took advantage of the long-term conceptual development support from the Institute of Geonics, Czech Academy of Sciences Nr. RVO: 68145535

\section{REFERENCES}

Applegate, C. 1999. A Europe of regions: Reflection of historiography of sub-national places in modern times. The American Historical Review 104. (4): 1157-1182.

Chromý, P. and JanŮ, H. 2003. Regional identity, activation of territorial communities and the potential of the development of peripheral regions. Acta Universitatis Carolinae Geographica 37. (1): 105-117.

Chromý, P., Kučerová, S. and Kučera, Z. 2004. Regional identity, contemporary and historical regions and the issue of relict borders - the case of Czechia. Region and Regionalism 9. (2): 9-19. 
DANĚK, P. 1993. Moravian and Silesian nationalities: A new phenomenon on the ethnic map of the Czech Lands? GeoJournal 30. (3): 249-254. Doi: 10.1080/00291951.2014.961540.

FICHTNER, U. 2006. Architektur grenzübergreifender Kooperation und raumbezogene Identität am südlichen Oberrhein. Europa Regional 14. (3): 102-116. http://www.cepsr.com/clanek.php?\%20ID=37.

IščUK, R. 2011. Moravská identita a její nové dimenze. Antropowebzin 11. (1): 74-81.

Jeffery, C. 2014. Introduction: Regional Public Attitudes beyond Methodological Nationalism. In Citizenship after the Nation State. Eds.: Henderson, A., Jeffery, C. and Wincott, D. London, Palgrave Macmillan, 1-30.

Keating, M. 1998. The New Regionalism in Western Europe: Territorial Restructuring and Political Change. Northampton, Edward Elgar, 242 p.

Lundén, T. and ZaLAmans, D. 2001. Local co-operation, ethnic diversity and state territoriality - The case of Haparanda and Tornio on the SwedenFinland border. GeoJournal 54. (1): 33-42.

Mareš, M. 2002. Evropská politika moravistických organizací. Central European Political Studies Review 4. (4): http://www.cepsr.com/clanek.php?ID=24

Musil, J. and Müller, J. 2008. Inner peripheries in the Czech Republic as a form of social exclusion. In Space and historical time as dimensions of social change. Ed.: MusiL, J. Prague, Charles University, 75-92.

Neumann, I.B. 1999. Uses of the other. "The East" in European identity formation. Manchester, Manchester University Press, $281 \mathrm{p}$.

Newman, D. 2006. The lines that continue to separate us: borders in our "borderless" world. Progress in Human Geography 30. (2): 146-161.

ODEHNAL, J. and ŠERÝ, M. 2012. Regional identity and its reflection in Czech human geography. Dela 38. 25-37.

PAAsI, A. 1986. The institutionalisation of regions: a theoretical framework for understanding the emergence of regions and the constitution of regional identity. Fennia 164. (1): 105-146.

PAAsI, A. 2001. Europe as a social process and discourse. Considerations of place, boundaries and identity. European Urban and Regional Studies 8. (7): 7-28.

PAAsI, A. 2002. Bounded spaces in the mobile World: Deconstructing "regional identity". Tijdschrift voor economische en sociale geografie 93. (2): 137-148.
PAasi, A. 2003. Region and place: Regional identity in question. Progress in Human Geography 27. (4): 475-485.

PAasi, A. 2009. The resurgence of the 'Region' and 'Regional Identity': theoretical perspectives and empirical observations on regional dynamics in Europe. Review of International Studies 35. (S1): 121-146.

PAinter, J. 2002. Multilevel citizenship, identity and regions in contemporary Europe. In Transnational democracy. Political spaces and border crossings. Ed.: Anderson, J. London, Routledge, 93-110.

Pileček, J. and JANČÁK, V. 2010. Je možné měřit sociální kapitál? Analýza územní diferenciace okresů Česka. Geografie 115. (1): 78-95.

Sedlacek, S., Kurka, B. and Maier, G. 2009. Regional identity: a key to overcome structural weaknesses in peripheral rural regions? European Countryside 1. (4): 180-201.

ŠEDo, J. 2002. Postavení Moravy dle Rokkanova modelu centrum - periferie. Central European Political Studies Review 4. (4):

Semian, M. and Chromý, P. 2014. Regional identity as a driver or a barrier in the process of regional development: A comparison of selected European experience. Norsk Geografisk Tijdskrift 68. (5): 263-270.

ŠERÝ, M. and ŠIMÁčEK, P. 2012. Perception of the historical border between Moravia and Silesia by residents of the Jeseník area as a partial aspect of their regional identity (Czech Republic). Moravian Geographical Reports 20. (2): 36-46.

SiweK, T. 2006. Czech Silesia: A periphery of the Czech state. Europa XXI 15. 145-150.

SiweK, T. 2012. Inner divisions of the Czech Republic. Geographia Polonica 85. (1): 23-31.

SiWEK, T. and Bogdová, K. 2007. Czech cultural-historical regions in the minds of their inhabitants. Czech Sociological Review 43. (5): 1039-1053.

SuChÁČEK, J., SEĎA, P. and FrIEdRICH, V. 2013. Regions and media from quantitative and qualitative perspectives: the case of Czech Republic. Acta Universitatis agriculturae and silviculturae Mendeliana Brunensis 61. (7): 2811-2819.

ToušEK, V., Ších, P. and VAšíčEK, P. 1991. Zemská hranice mezi Čechami a Moravou. Sborník České geografické společnosti 96. (1): 45-48. 


\title{
Minsk and Budapest, the two capital cities
}

\author{
Edited by \\ LÁsZló Jeney and DÁvid Karácsonyi
}

Department of Economic Geography and Futures Studies, Corvinus University of Budapest; Geographical Institute RCAES HAS; Faculty of Geography, Belarusian State University; Institute for Nature Management, National Academy of Sciences of Belarus

Budapest, 2015. 194 p.

While Budapest used to be the bridge between the West and East in Central Europe, Minsk seems to be in a similar role between the Russian and the EU-Polish influence zones. It means that both capitals are situated on the frontiers between the Euro-Atlantic and the Euro-Asian macro regions. Besides their situations, their similarity in size renders the comparison and the cooperation obvious to proceed. This book is based on the mutual

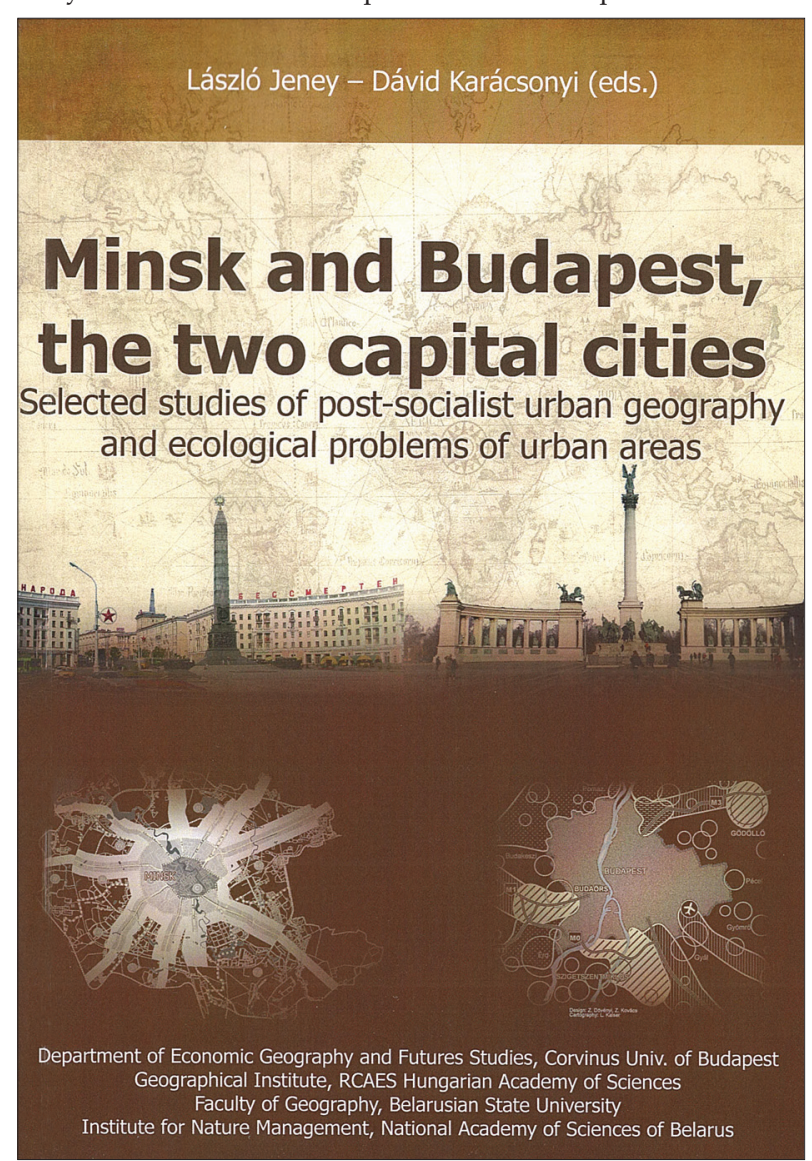

co-operation of Hungarian and Belarussian geographers and gives a scientific outlook not only on the socio-economic development of the two cities but on the urban climate, environment and ecology as well. Hungarian authors of the book introduce Budapest as a Central European metropolis with its historical trajectories and the results of the post-socialist transformation. They also demonstrate the main features of large housing estates and the results of their rehabilitation. Authors from Belarus show the major issues of spatial structure planning of Minsk in a similar context, describing the past and the present changes taking place in the spatial structure of the metropolis. The integrated assessment of the state of urban environment in Minsk is examined also focusing on the ecological frame of the environmental planning in urban agglomerations. The volume serves as a good starting point of a fruitful co-operation between Belarussian and Hungarian geographers dealing with a social and physical urban environment, the state of which deserves extra attention especially in East Central and Eastern Europe.

Copies are available:

Library, Geographical Institute of RCAES HAS, H-1112 Budapest, Budaörsi u. 44.

E-mail: magyar.arpad@csfk.mta.hu 